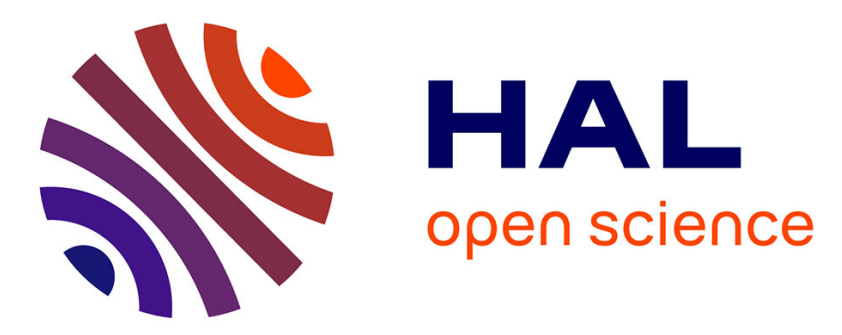

\title{
Impact of biogenic emissions on air quality over Europe and North America
}

Karine Sartelet, Florian Couvidat, Christian Seigneur, Yelva Roustan

\section{To cite this version:}

Karine Sartelet, Florian Couvidat, Christian Seigneur, Yelva Roustan. Impact of biogenic emissions on air quality over Europe and North America. Atmospheric Environment, 2012, 53, pp.131 - 141. 10.1016/j.atmosenv.2011.10.046 . hal-01694102

\section{HAL Id: hal-01694102 \\ https://hal-enpc.archives-ouvertes.fr/hal-01694102}

Submitted on 8 Feb 2018

HAL is a multi-disciplinary open access archive for the deposit and dissemination of scientific research documents, whether they are published or not. The documents may come from teaching and research institutions in France or abroad, or from public or private research centers.
L'archive ouverte pluridisciplinaire HAL, est destinée au dépôt et à la diffusion de documents scientifiques de niveau recherche, publiés ou non, émanant des établissements d'enseignement et de recherche français ou étrangers, des laboratoires publics ou privés. 


\title{
Impact of biogenic emissions on air quality over Europe and North America
}

\author{
Karine N. Sartelet*, Florian Couvidat, Christian Seigneur, Yelva Roustan \\ CEREA, Joint Laboratory École des Ponts ParisTech/EDF R E D, Université Paris-Est, 77455 Marne la Vallée Cedex 2, France
}

\section{A R T I C L E I N F O}

\section{Article history:}

Received 6 June 2011

Received in revised form

18 October 2011

Accepted 20 October 2011

\section{Keywords:}

Biogenic

Anthropogenic

Emission

Ozone

Particles

PM

\begin{abstract}
A B S T R A C T
This study aims to compare the relative impact of biogenic emissions on ozone $\left(\mathrm{O}_{3}\right)$ and particulate matter (PM) concentrations between North America (NA) and Europe. The simulations are conducted with the Polyphemus air quality modeling system over July and August 2006. Prior to the sensitivity study on the impact of biogenic emissions on air quality, the modeling results are compared to observational data, as well as to the concentrations obtained by other modeling teams of the Air Quality Model Evaluation International Initiative (AQMEII) study.

Over Europe, three distinct emission inventories are used. Model performance is satisfactory for $\mathrm{O}_{3}$, $\mathrm{PM}_{10}$ and $\mathrm{PM}_{2.5}$ with all inventories with respect to the criteria described in the literature. Furthermore, the rmse and errors are lower than the average rmse and errors of the AQMEII simulations. Over North America, the model performance satisfies the criteria described in the literature for $\mathrm{O}_{3}, \mathrm{PM}_{10}$ and $\mathrm{PM}_{2.5}$. Polyphemus results are within the range of the AQMEII model results. Although the rmse and errors are higher than the average of the AQMEII simulations for $\mathrm{O}_{3}$, they are lower for $\mathrm{PM}_{10}$ and $\mathrm{PM}_{2.5}$.

The impact of biogenic and anthropogenic emissions on $\mathrm{O}_{3}$ and PM concentrations is studied by removing alternatively biogenic and anthropogenic emissions in distinct simulations. Because biogenic species interact strongly with $\mathrm{NO}_{\mathrm{x}}$, the impact of biogenic emissions on $\mathrm{O}_{3}$ concentrations varies with variations of the Volatile Organic Compound ( $\mathrm{VOC}) / \mathrm{NO}_{\mathrm{x}}$ ratio. This impact is larger over NA than Europe. $\mathrm{O}_{3}$ decreases by $10-11 \%$ on average over Europe and $20 \%$ over NA. Locally, the relative impact is also higher in NA (60\% maximum) than in Europe (35\% maximum). $\mathrm{O}_{3}$ decreases near large urban centers where biogenic emissions are large (e.g. Los Angeles, Chicago, Houston in NA, Milan in Europe).

Most of secondary organic aerosols (SOA) formed at the continental scale over Europe and NA are biogenic aerosols. Eliminating biogenic emissions reduces SOA by $72-88 \%$ over Europe and by $90 \%$ over NA. However, biogenic SOA are not only impacted by biogenic but also by anthropogenic emissions: eliminating all anthropogenic emissions affects oxidant levels and the absorbing carbon mass, reducing the formation of SOA by $15-16 \%$ over Europe and by about $10 \%$ over NA; Furthermore, locally, the reduction may be as large as 50\%, especially over large urban centers in Europe and NA.
\end{abstract}

(c) 2011 Elsevier Ltd. All rights reserved.

\section{Introduction}

Ozone $\left(\mathrm{O}_{3}\right)$ and particulate matter $(\mathrm{PM})$ concentrations are believed to contribute to adverse health effects (Ostro and Chestnut, 1998) and climate change (Yu et al., 2006). Emissions of volatile organic compounds (VOC) and nitrogen oxides $\left(\mathrm{NO}_{\mathrm{x}}\right)$ affect both $\mathrm{O}_{3}$ and PM concentrations. Emissions are from different origins: anthropogenic, biogenic, marine, natural and re-suspended dust and biomass burning. Biogenic VOC (BVOC) emissions are highest in summer (e.g. Guenther et al., 1995; Steinbrecher et al., 2009). During the summer heat wave of $2006, \mathrm{O}_{3}$ concentrations frequently exceeded air quality standards over Europe (Struzewska

\footnotetext{
* Corresponding author.

E-mail address: sartelet@cerea.enpc.fr (K.N. Sartelet).
}

and Kaminski, 2008). The year 2006 was also the second-hottest year in North America (NA) since the mid 1900s. As BVOC emissions depend on light and temperature, their impact on air quality during the summer 2006 may be high. Because precursor emission regulations can only target anthropogenic emissions, high biogenic emissions are not controllable and it is essential to understand how they may increase difficulties in meeting air quality standards via their interactions with anthropogenic species.

Over Europe, Curci et al. (2009) showed that for the years 1997, 2000, 2001 and 2003, BVOC emissions increased summer daily $\mathrm{O}_{3}$ maxima by $5 \%$ on average. They also found that the average impact is higher during the hot summer of 2003 than during the other cooler summers.

Over the northeastern United States, Pun et al. (2002) estimated the contribution of biogenic emissions to $\mathrm{O}_{3}$ and $\mathrm{PM}_{2.5}$ for a few days in July 1995 . They showed that the contribution to $\mathrm{O}_{3}$ was 
lower than $23 \%$. The contribution to $\mathrm{PM}_{2.5}$ was low (4-13\%). Pun et al. (2002) argued that it is because of the long life-time of $\mathrm{PM}_{2.5}$, and the relatively short time period and small spatial domain of the simulations. In their simulations, biogenic secondary organic aerosols (SOA) only contributed to a small fraction of $\mathrm{PM}_{2.5}$ and isoprene SOA was not modeled. Mueller and Mallard (2011) studied the relative contributions of natural to total emissions over the United States. They found that biogenic emissions were the primary source of fine particles in all parts of the country. For the eastern United States, Hogrefe et al. (2011) found that the impact of uncertainties in biogenic estimates from two models on $\mathrm{O}_{3}$ and $\mathrm{PM}_{2.5}$ is significant. Koo et al. (2011) studied the impact of natural emissions on anthropogenic emission control strategies, and found substantial uncertainties in current representation of natural sources, such as lightning NO emissions, which affect $\mathrm{O}_{3}$ concentrations in the southeastern US where biogenic VOC emissions are large.

Anthropogenic $\mathrm{NO}_{\mathrm{x}}$ concentrations may increase the oxidation of BVOC and the formation of $\mathrm{O}_{3}$ and PM. Curci et al. (2009) and Pun et al. (2002) found that $\mathrm{O}_{3}$ production is more impacted by BVOC emissions in metropolitan regions than in rural areas. $\mathrm{O}_{3}$ production depends on the initial amounts of VOC (non-methane VOC)/ $\mathrm{NO}_{\mathrm{x}}$ ratio (in ppbC/ppb, see the ozone isopleth diagram of Seinfeld and Pandis (1998) for example). The variations of this $\mathrm{VOC} / \mathrm{NO}_{\mathrm{x}}$ ratio is used in this paper to understand the variation of the $\mathrm{O}_{3}$ production regime. Hoyle et al. (2011) detailed the mechanisms through which the anthropogenic emissions enhance the formation of biogenic SOA: anthropogenic emissions impact the concentration of oxidants $\left(\mathrm{O}_{3}, \mathrm{OH}, \mathrm{NO}_{3}\right)$, which oxidize BVOC to form semi-volatile species, and anthropogenic primary organic aerosols may serve as an absorbing medium favoring their condensation. Carlton et al. (2010) estimated that more than $50 \%$ of biogenic SOA in the eastern U.S. can be controlled via the influence of anthropogenic emissions on biogenic SOA.

For the Air Quality Model Evaluation International Initiative (AQMEII) study, several air quality models were compared over North America (NA) and Europe (Rao et al., 2011). One of these models (Polyphemus) is used here to investigate the effect of biogenic emissions on air quality. The model is described in the first section. Then, its performance is evaluated by comparisons to available observations in the Ensemble system (Bianconi et al., 2004) as well as by comparisons with other models of the AQMEII study. Over Europe, four simulations are conducted with and without biomass burning emissions and with different anthropogenic emission inventories and biogenic emission schemes. Over North America (NA), the simulation is conducted using the default data provided for the AQMEII study. Finally, the relative impacts of biogenic and anthropogenic emissions on air quality over Europe and NA are estimated and compared for the different Polyphemus simulations.

\section{Model description}

The Polyphemus air quality modeling platform (http://cerea. enpc.fr/polyphemus) is used here with the chemistry transport model Polair3D. Polyphemus/Polair3D has already been used for many applications at the continental scale over Europe and East Asia (e.g. Sartelet et al., 2007, 2010; Kim et al., 2009; Roustan et al., 2010; Kim et al., 2011b).

For gas-phase chemistry, the Regional Atmospheric Chemistry Mechanism (RACM, Stockwell et al., 1997) is used over Europe and the Carbon-Bond Mechanism (CB05, Yarwood et al., 2005) over NA. Over NA, photolysis rates are computed online, that is the influence of particles on photolysis rates is taken into account (Real and Sartelet, 2011). The aerosol model used is SIREAM-SuperSorgam
(Debry et al., 2007; Kim et al., 2011a). It models coagulation and condensation/evaporation. It uses a standard SOA formulation with hydrophobic absorption of SOA into organic particles. The SOA precursors are aromatics, long-chain alkanes, long-chain alkenes, isoprene, monoterpenes and sesquiterpenes. The biogenic SOA formation varies depending on the $\mathrm{NO}_{\mathrm{x}}$ regime.

Simulations are performed from 1 July 2006 to 31 August 2006. In all simulations, 9 vertical levels are considered from the ground to $12 \mathrm{~km} \mathrm{(40} \mathrm{m,} 120 \mathrm{~m}, 300 \mathrm{~m}, 800 \mathrm{~m}, 1500 \mathrm{~m}, 2400 \mathrm{~m}, 3500 \mathrm{~m}$, $6000 \mathrm{~m}, 12,000 \mathrm{~m}$ ). The Global Land Cover 2000 (GLC2000) map with 23 categories is used for land-use coverage. Initial and boundary conditions are the default AQMEII conditions provided by ECMWF-GEMS. Sea-salt emissions are parameterized following Monahan et al. (1986). The emitted mass of sea-salt is assumed to be made of $30.61 \%$ of sodium, $55.025 \%$ of chloride and $7.68 \%$ of sulfate (Seinfeld and Pandis, 1998). Over Europe, the horizontal domain is $\left(35^{\circ} \mathrm{N}-70^{\circ} \mathrm{N} ; 15^{\circ} \mathrm{W}-35^{\circ} \mathrm{E}\right)$ with a resolution of $0.25^{\circ} \times 0.25^{\circ}$. The meteorological data correspond to the default MM5 data provided for the AQMEII inter-comparison with 32 vertical levels (Vautard et al., 2012). In the first of the four simulations conducted over Europe, and labeled Pol 1, anthropogenic emissions are the default AQMEII emissions data provided by TNO (Pouliot et al., 2012). They are referred to as the TNO anthropogenic emission inventory. Biogenic emissions are computed as in Simpson et al. (1999), and referred to as the Simpson biogenic emission scheme. Biogenic (terpene) emissions are distributed among pinene (62.54\%), limonene (37.03\%) and sesquiterpene (humulene, 0.43\%), following Johnson et al. (2006) and Helmig et al. (1999a,b). Biomass burning emissions provided by Finnish Meteorological Institute (FMI) for AQMEII are also used in one simulation. Following Mikhail Sofief (communication on AQMEII web site), 50\% is emitted between the surface and $200 \mathrm{~m}$, and the remaining 50\% is emitted between $200 \mathrm{~m}$ and $1000 \mathrm{~m}$. The fire PM emissions are assumed to consist of $70 \%$ of $\mathrm{PM}_{2.5}$ and $30 \%$ of $\mathrm{PM}_{10}-\mathrm{PM}_{2.5}$. For gaseous species emissions from biomass burning, the PM emission rate is multiplied by 7.88 and then split amongst $\mathrm{CO}, \mathrm{HCHO}, \mathrm{NO}_{\mathrm{x}}$, $\mathrm{NH}_{3}$ and $\mathrm{SO}_{2}$ according to the following fractions: 0.94, 0.013, 0.029, 0.014 and 0.004 , respectively. In the other three simulations conducted over Europe, biomass burning is ignored, because $\mathrm{PM}_{2.5}$ is strongly over-estimated over Portugal when biomass burning emissions are used. The second simulation labeled "Pol 2" uses the TNO emission inventory for anthropogenic emissions and Simpson for biogenic emissions, as Pol 1. The third simulation, labeled "Pol 3", uses the European Monitoring and Evaluation Program (EMEP, http://www.emep.int/) expert inventory for 2006 and Simpson for biogenic emissions. The time distribution of EMEP emissions, as well as the speciation are detailed in Sartelet et al. (2007). The fourth simulation, labeled "Pol 4", uses the EMEP emission inventory for anthropogenic emissions and the Model of Emissions of Gases and Aerosols from Nature with the EFv2.1 dataset (MEGAN, Guenther et al., 2006). Differences between the MEGAN and Simpson emission schemes are discussed elsewhere (Steinbrecher et al., 2009). The two biogenic emission schemes use different methodologies: MEGAN uses canopy-scale emission factors based on leaf area index obtained from the standard MEGAN LAIv database (MEGAN-L, Guenther et al., 2006) whereas Simpson uses leafscale emission factors based on GLC2000 land-use categories. Furthermore, although terpene emissions are distributed amongst pinene, limonene and sesquiterpenes with constant factors, different emission factors are used for several species in MEGAN. Table 1 compares the domain-mean Simpson and MEGAN biogenic emissions. Except for sesquiterpenes, MEGAN emissions are lower than Simpson emissions, especially over the northeastern part of the domain, such as over Finland. Differences in the spatial distribution are also observed, such as in Poland, Croatia or central 
Table 1

Domain-mean Simpson and MEGAN biogenic emissions (in $\mu \mathrm{g} \mathrm{m}^{-2} \mathrm{~s}^{-1}$ ).

\begin{tabular}{lll}
\hline & Simpson & MEGAN \\
\hline Isoprene & 0.0799 & 0.0312 \\
Terpenes & 0.0436 & 0.01792 \\
Sesquiterpenes & 0.000188 & 0.00129 \\
NO & 0.00118 & 0.00108 \\
\hline
\end{tabular}

France. Table 2 summarizes the emission inventories used in the four simulations.

Over North America, the horizontal domain is $\left(24^{\circ} \mathrm{N}-53.75^{\circ} \mathrm{N}\right.$; $125.5^{\circ} \mathrm{W}-64^{\circ} \mathrm{W}$ ) with a resolution of $0.25^{\circ} \times 0.25^{\circ}$. The meteorological data correspond to the default WRF data provided for the AQMEII inter-comparison (Vautard et al., 2012). As Polyphemus uses a Lat-Lon projection versus Lambert for WRF, the meteorological data do not cover the whole computational domain. Therefore, the Polyphemus domain $\left(24^{\circ} \mathrm{N}-53.75^{\circ} \mathrm{N}\right.$; $125.5^{\circ} \mathrm{W}-64^{\circ} \mathrm{W}$ ) is slightly smaller than the AQMEII domain $\left(23.5^{\circ} \mathrm{N}-58.5^{\circ} \mathrm{N} ; 130^{\circ} \mathrm{W}-59.5^{\circ} \mathrm{W}\right)$. For the remaining few grid cells missing in the southwestern and southeastern parts of the domain over the ocean, the same meteorological fields as those along the boundary are used. Anthropogenic, biogenic from BEIS3.14 and biomass burning emissions are those provided by US-EPA for AQMEII (Pouliot et al., 2012).

\section{Base simulations over Europe and North America}

\subsection{Model performance evaluation}

The following statistics are computed for comparing the surface levels from the base case simulation with observations between 7 July 2006 and 31 August 2006: root mean square error (rmse), mean fractional error (mfe), mean fractional bias ( $\mathrm{mfb})$, and correlation coefficient $(r)$. For $\mathrm{O}_{3}$, the mean normalized gross error (mnge) and mean normalized gross bias (mngb) are also computed with a cutoff of $80 \mu \mathrm{g} \mathrm{m}^{-3}$ (i.e. about $40 \mathrm{ppb}$ ). Russell and Dennis (2000) recommend performance criteria for hourly $\mathrm{O}_{3}$ to be mngb $\leq \pm 15 \%$ and mnge $\leq 30 \%$. For PM, Boylan and Russell (2006) propose that a model performance goal is met when both the mfe is less than or equal to $+50 \%$ and the $\mathrm{mfb}$ is within $\pm 30 \%$ respectively, and a model performance criterion is met when both mfe $\leq+75 \%$ and $-60 \% \leq \mathrm{mfb} \leq 60 \%$. The first week is excluded when computing statistics to allow for model initialization and spin-up. Observational data at rural and suburban stations were obtained from the ensemble system. The results of simulations provided by other modeling teams at these stations were also obtained and compared with the results of this modeling study. Over Europe, the observational data include stations from Airbase (http://air-climate. eionet.europa.eu/databases/airbase) and EMEP (http://tarantula. nilu.no/projects/ccc/emepdata.html) databases. Over NA, these data include stations from Interagency Monitoring of Protected Visual Environments (IMPROVE, http://vista.cira.colostate.edu/ improve/), the U.S. Environmental Protection Agency (EPA) Aerometric Information Retrieval System (AIRS, http://www.epa.gov/ air/data/index.html), and the Environment Canada National Air

Table 2

Emission inventories used in the four simulations conducted over Europe with Polyphemus.

\begin{tabular}{lllll}
\hline & Pol 1 & Pol 2 & Pol 3 & Pol 4 \\
\hline Anthropogenic emissions & TNO & TNO & TNO & EMEP \\
Biogenic emissions & Simpson & Simpson & Simpson & MEGAN \\
Biomass burning emissions & Yes & No & No & No \\
\hline
\end{tabular}

Table 3

Comparisons to observations for surface $\mathrm{O}_{3}$ over Europe (concentrations and rmse are in $\mu \mathrm{g} \mathrm{m}^{-3}$ ).

\begin{tabular}{llllllll}
\hline $\mathrm{O}_{3}$ - Europe & Pol 1 & Pol 2 & Pol 3 & Pol 4 & \multicolumn{2}{l}{ AQMEII models } \\
\cline { 3 - 7 } & & & & & Min & Mean & Max \\
\hline Number of stations & 796 & 796 & 796 & 796 & 790 & 795.4 & 796 \\
Mean obs & 73.0 & 73.0 & 73.0 & 73.0 & 73.0 & 73.0 & 73.1 \\
Mean sim & 68.7 & 67.0 & 69.3 & 67.5 & 60.9 & 72.4 & 97.0 \\
rmse & 29.8 & 29.9 & 29.2 & 28.6 & 30.0 & 32.8 & 38.8 \\
correlation & $65.8 \%$ & $66.4 \%$ & $67.3 \%$ & $69.8 \%$ & $56.6 \%$ & $62.8 \%$ & $68.6 \%$ \\
mfb & $-24.5 \%$ & $-27.3 \%$ & $-23.2 \%$ & $-25.2 \%$ & $-39.0 \%$ & $-21.7 \%$ & $5.7 \%$ \\
mfe & $28.3 \%$ & $30.0 \%$ & $27.1 \%$ & $28.1 \%$ & $17.1 \%$ & $29.5 \%$ & $41.8 \%$ \\
mngb & $-19.6 \%$ & $-22.1 \%$ & $-18.7 \%$ & $-20.6 \%$ & $-29.4 \%$ & $-15.8 \%$ & $8.3 \%$ \\
mnge & $24.0 \%$ & $25.1 \%$ & $23.1 \%$ & $23.8 \%$ & $18.3 \%$ & $24.9 \%$ & $32.6 \%$ \\
\hline
\end{tabular}

Pollution Surveillance network (Cast and Naps) databases. Hourly concentration data are used for gaseous species and daily data are used for particulate matter (PM).

\subsubsection{Over Europe}

Over Europe, the 4 different Polyphemus simulations are compared to observations for $\mathrm{O}_{3}, \mathrm{PM}_{10}$ and $\mathrm{PM}_{2.5}$ in Tables 3-5 respectively. Comparisons for $\mathrm{NO}_{2}$ and $\mathrm{SO}_{2}, \mathrm{PM}_{10}$ sulfate, $\mathrm{PM}_{10}$ nitrate and $\mathrm{PM}_{10}$ ammonium are presented in the Supplementary electronic materials. The comparison of model results with observations is also conducted for 9 different models that participated to the AQMEII inter-comparisons, not including Polyphemus, in order to compare the performances. The mean of the statistics of the AQMEII models is computed as well as the minimum and maximum values.

For all pollutants, the different simulations using Polyphemus perform well according to the performance criteria detailed above and they are within the range of results obtained by other AQMEII models.

For hourly $\mathrm{O}_{3}$, the average simulated concentration is close to the average measured concentration, although it is slightly lower (73.0 $\mu \mathrm{g} \mathrm{m}^{-3}$ measured against between 67.0 and $69.3 \mu \mathrm{g} \mathrm{m}^{-3}$ simulated with rmse between 28.6 and $29.9 \mu \mathrm{g} \mathrm{m}^{-3}$ ). The mngb is slightly higher than the range of the model performance criterion of Russell and Dennis (2000) (within $\pm 15 \%$ ). However, the mnge is well within the range of the model performance criterion of Russell and Dennis (2000) ( $\leq 30 \%)$. The different Polyphemus simulations compare well to other AQMEII simulations: the highest rmse of the Polyphemus simulations is lower than the lowest rmse of the AQMEII simulations, while the correlations of Polyphemus are close to the highest correlation of the AQMEII simulations or higher for Pol 4. Other errors and bias are close to the average of the AQMEII simulations. The differences between the different Polyphemus simulations are much lower than differences between the different AQMEII simulations.

\section{Table 4}

Comparisons to observations for surface $\mathrm{PM}_{10}$ over Europe (concentrations and rmse are in $\mu \mathrm{g} \mathrm{m}^{-3}$ ).

\begin{tabular}{llllllll}
\hline PM $_{10}$ - Europe & Pol 1 & Pol 2 & Pol 3 & Pol 4 & \multicolumn{2}{l}{ AQMEII models } \\
\cline { 3 - 8 } & & & & & Min & Mean & Max \\
\hline Number of stations & 235 & 235 & 235 & 235 & 235 & 235 & 235 \\
Mean obs & 23.2 & 23.2 & 23.2 & 23.2 & 23.2 & 23.2 & 23.2 \\
Mean sim & 21.1 & 19.3 & 19.9 & 18.5 & 6.2 & 12.9 & 23.4 \\
rmse & 15.9 & 14.7 & 14.7 & 15.1 & 16.2 & 23.2 & 24.6 \\
Correlation & $18.6 \%$ & $19.1 \%$ & $19.6 \%$ & $18.9 \%$ & $8.2 \%$ & $17.3 \%$ & $25.0 \%$ \\
mfb & $-5.2 \%$ & $-11.4 \%$ & $-9.0 \%$ & $-16.3 \%$ & $-111.0 \%$ & $-64.3 \%$ & $3.9 \%$ \\
mfe & $46.9 \%$ & $46.6 \%$ & $46.3 \%$ & $48.7 \%$ & $44.5 \%$ & $80.8 \%$ & $112.7 \%$ \\
\hline
\end{tabular}


Table 5

Comparisons to observations for surface $\mathrm{PM}_{2.5}$ over Europe (concentrations and rmse are in $\mu \mathrm{g} \mathrm{m}^{-3}$ ).

\begin{tabular}{llllllll}
\hline $\mathrm{PM}_{2.5}$ - Europe & Pol 1 & Pol 2 & Pol 3 & Pol 4 & \multicolumn{2}{l}{ AQMEII models } \\
\cline { 5 - 8 } & & & & & Min & Mean & Max \\
\hline Number of stations & 39 & 39 & 39 & 39 & 39 & 39 & 39 \\
Mean obs & 13.3 & 13.3 & 13.3 & 13.3 & 13.3 & 13.3 & 13.3 \\
Mean sim & 19.2 & 17.7 & 18.6 & 17.4 & 5.0 & 12.3 & 21.4 \\
rmse & 14.0 & 12.0 & 12.7 & 12.2 & 11.4 & 24.1 & 69.2 \\
Correlation & $14.1 \%$ & $10.6 \%$ & $9.2 \%$ & $9.1 \%$ & $3.2 \%$ & $11.8 \%$ & $21.1 \%$ \\
mfb & $36.8 \%$ & $31.7 \%$ & $35.7 \%$ & $28.9 \%$ & $-85.7 \%$ & $-30.5 \%$ & $44.9 \%$ \\
mfe & $59.6 \%$ & $57.0 \%$ & $59.0 \%$ & $57.4 \%$ & $55.1 \%$ & $72.3 \%$ & $94.2 \%$ \\
\hline
\end{tabular}

The average $\mathrm{PM}_{10}$ concentration is well simulated, although it is slightly under-estimated for Pol 2, Pol 3 and Pol $4\left(23.2 \mu \mathrm{g} \mathrm{m}^{-3}\right.$ measured against between 18.5 and $21.1 \mu \mathrm{g} \mathrm{m}^{-3}$ simulated, and rmse between 28.6 and $29.9 \mu \mathrm{g} \mathrm{m}^{-3}$ ). The model performance goal of Boylan and Russell (2006) is met for all Polyphemus simulations as the $\mathrm{mfb}$ is within $\pm 30 \%$, and the mfe is lower than $50 \%$. The different Polyphemus simulations compare well to other AQMEII simulations: the highest rmse is lower than the lowest rmse of the AQMEII simulations. The correlation of Polyphemus are above the average of the correlations of the AQMEII simulations. As for $\mathrm{O}_{3}$, the differences between the different Polyphemus simulations are much lower than the differences between the different AQMEII simulations.

The average simulated $\mathrm{PM}_{2.5}$ concentration is higher than the average measured $\mathrm{PM}_{2.5}$ concentration $\left(13.3 \mu \mathrm{g} \mathrm{m} \mathrm{m}^{-3}\right.$ measured against between 17.4 and $19.2 \mu \mathrm{g} \mathrm{m} \mathrm{m}^{-3}$ simulated, with rmse between 12.0 and $14.0 \mu \mathrm{g} \mathrm{m}^{-3}$ ). The model performance goal of Boylan and Russell (2006) is met for the $\mathrm{mfb}$ for Pol 4, but it is not met for Pol 1-Pol 3. The model performance goal is not met for the mfe. However the model performance criteria are met for both the $\mathrm{mfb}$ and the mfe for all Polyphemus simulations, as the $\mathrm{mfb}$ and mfe are within $\pm 60 \%$ and lower than $75 \%$ respectively. The different Polyphemus simulations compare well to other AQMEII simulations: the mfe and the rmse are in the low range of the AQMEII models, while correlation is in the high range. As for $\mathrm{O}_{3}$ and $\mathrm{PM}_{10}$, the differences between the different Polyphemus simulations are lower than differences between the different AQMEII simulations.

Over Portugal, where high-intensity biomass burning occurred, taking biomass burning into account (Pol 1) leads to a large overestimation of $\mathrm{PM}_{2.5}$. The mean measured concentration at the 6 rural Airbase stations over Portugal is equal to $14.3 \mu \mathrm{g} \mathrm{m}^{-3}$. The simulated concentration is equal to $34.1 \mu^{-3} \mathrm{~m}^{-3}$ for Pol $1,15.2$ for Pol 2, 17.1 for Pol 3 and $14.0 \mu \mathrm{g} \mathrm{m}^{-3}$ for Pol 3. One of the reasons for this large over-estimation of $\mathrm{PM}_{2.5}$ at the ground over Portugal for Pol 1 is related to the emission height of biomass burning. For example, Hodzic et al. (2007) relate the emission height to the

Table 6

Comparisons to observations for surface $\mathrm{O}_{3}$ over NA (concentrations and rmse are in $\mathrm{ppb})$.

\begin{tabular}{lllll}
\hline \multirow{2}{*}{$\mathrm{O}_{3}-\mathrm{NA}$} & Polyphemus & \multicolumn{3}{l}{ AQMEII models } \\
\cline { 3 - 5 } & & Min & Mean & Max \\
\hline Number of stations & 634 & 634 & 634 & 634 \\
Mean obs & 34.0 & 34.0 & 34.0 & 34.0 \\
Mean sim & 43.6 & 33.8 & 39.4 & 44.6 \\
rmse & 20.2 & 15.3 & 17.5 & 19.9 \\
Correlation & $60.4 \%$ & $61.9 \%$ & $66.0 \%$ & $69.5 \%$ \\
mfb & $-1.3 \%$ & $-19.2 \%$ & $-7.4 \%$ & $1.7 \%$ \\
mfe & $24.7 \%$ & $18.7 \%$ & $25.3 \%$ & $39.9 \%$ \\
mngb & $3.8 \%$ & $-12.3 \%$ & $-2.2 \%$ & $5.5 \%$ \\
mnge & $25.6 \%$ & $18.5 \%$ & $23.7 \%$ & $34.5 \%$ \\
\hline
\end{tabular}

Table 7

Comparisons to observations for surface $\mathrm{PM}_{10}$ over NA (concentrations and rmse are in $\mu \mathrm{g} \mathrm{m}^{-3}$ ).

\begin{tabular}{lllll}
\hline $\mathrm{PM}_{10}-\mathrm{NA}$ & Polyphemus & \multicolumn{3}{l}{ AQMEII models } \\
\cline { 3 - 5 } & & Min & Mean & Max \\
\hline Number of stations & 638 & 638 & 638 & 638 \\
Mean obs & 28.0 & 28.0 & 28.0 & 28.0 \\
Mean sim & 15.1 & 5.4 & 13.8 & 30.7 \\
rmse & 27.5 & 24.5 & 28.4 & 32.6 \\
Correlation & $15.1 \%$ & $11.4 \%$ & $20.4 \%$ & $29.3 \%$ \\
mfb & $-49.4 \%$ & $-122.4 \%$ & $-65.8 \%$ & $19.1 \%$ \\
mfe & $67.5 \%$ & $49.7 \%$ & $81.6 \%$ & $123.7 \%$ \\
\hline
\end{tabular}

intensity of fire. They estimate that $95 \%$ of emissions of the largest fires over Portugal is emitted above the boundary layer, whereas in Pol 1 all the pollutants are emitted in the boundary layer. Therefore, Pol 1 is not considered in the impact study conducted below.

\subsubsection{Over North America}

Over NA, only one Polyphemus simulation is performed using the default AQMEII emission inputs. It is compared to observations for $\mathrm{O}_{3}, \mathrm{PM}_{10}$ and $\mathrm{PM}_{2.5}$ in Tables $6-8$, respectively. The comparison to observations is also conducted for 6 different models that participated to the AQMEII inter-comparisons. Performance evaluation for $\mathrm{NO}_{2}$ and $\mathrm{SO}_{2}$ is presented in the Supplementary electronic materials, as well as for elemental carbon of $\mathrm{PM}_{2.5}$, organic matter of $\mathrm{PM}_{2.5}$, sulfate of $\mathrm{PM}_{2.5}$, nitrate of $\mathrm{PM}_{2.5}$ and ammonium of $\mathrm{PM}_{2.5}$.

For $\mathrm{O}_{3}, \mathrm{PM}_{10}$ and $\mathrm{PM}_{2.5}$, the Polyphemus simulation performs well according to the performance criteria detailed above and it is within the range of results obtained by other AQMEII models.

Although $\mathrm{O}_{3}$ is over-estimated by Polyphemus (34.0 ppb measured and $43.6 \mathrm{ppb}$ simulated with a rmse of $20.1 \mathrm{ppb}$ ), the Polyphemus simulation satisfies the model performance criterion of Russell and Dennis (2000): the mngb and mnge are within $\pm 15 \%$ and lower than $30 \%$. Compared to the other AQMEII models, the rmse of the Polyphemus simulation is slightly higher than the higher rmse of all models, but the mfe and mnge correspond to the average of all models.

For $\mathrm{PM}_{10}$, the average simulated $\mathrm{PM}_{10}$ concentration is underestimated $\left(28.0 \mu \mathrm{g} \mathrm{m} \mathrm{m}^{-3}\right.$ measured and $15.1 \mu \mathrm{g} \mathrm{m}^{-3}$ simulated with a rmse of $27.5 \mu \mathrm{g} \mathrm{m}^{-3}$ ). The model performance goal of Boylan and Russell (2006) is not met, but the model performance criterion of Boylan and Russell (2006) is met as the mfb is within $\pm 60 \%$ and the mfe is less than 75\%. Compared to the other AQMEII models, the rmse and mfe of the Polyphemus simulation are lower than the average of all models.

For $\mathrm{PM}_{2.5}$, the average simulated $\mathrm{PM}_{2.5}$ concentration is overestimated $\left(12.9 \mathrm{\mu g} \mathrm{m}^{-3}\right.$ measured and 16.1 simulated with a rmse of $9.3 \mu \mathrm{g} \mathrm{m}^{-3}$ ). However, the model performance goal of Boylan and

Table 8

Comparisons to observations for surface $\mathrm{PM}_{2.5}$ over NA (concentrations and rmse are in $\mu \mathrm{g} \mathrm{m}^{-3}$ ).

\begin{tabular}{lllll}
\hline $\mathrm{PM}_{2.5}-\mathrm{NA}$ & Polyphemus & \multicolumn{3}{l}{ AQMEII models } \\
\cline { 3 - 5 } & & Min & Mean & Max \\
\hline Number of stations & 733 & 733 & 733 & 733 \\
Mean obs & 12.9 & 12.9 & 12.9 & 12.9 \\
Mean sim & 16.1 & 6.7 & 12.6 & 28.2 \\
rmse & 9.3 & 7.0 & 9.6 & 20.0 \\
Correlation & $50.4 \%$ & $47.5 \%$ & $60.3 \%$ & $67.0 \%$ \\
mfb & $23.1 \%$ & $-59.6 \%$ & $-11.6 \%$ & $75.4 \%$ \\
mfe & $47.7 \%$ & $33.1 \%$ & $52.5 \%$ & $79.6 \%$ \\
\hline
\end{tabular}




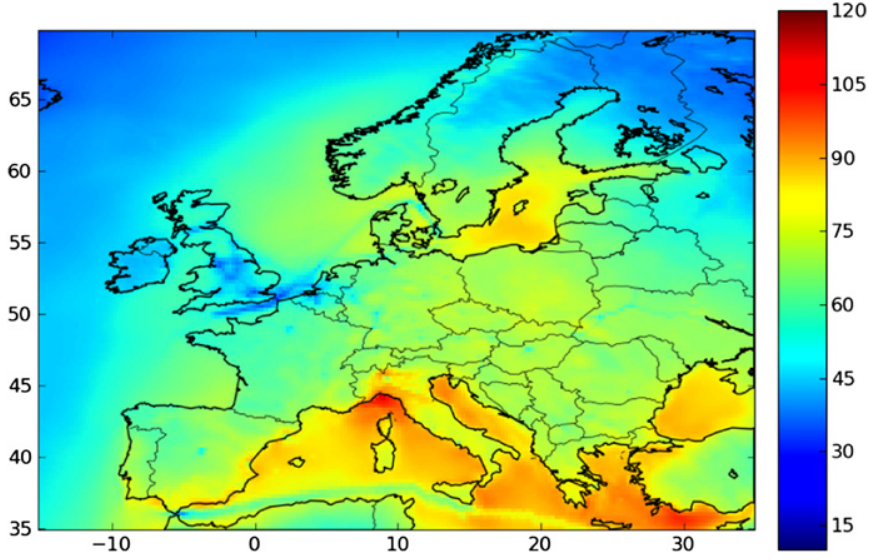

Fig. 1. Surface $\mathrm{O}_{3}$ concentrations (in $\mu \mathrm{g} \mathrm{m}^{-3}$ ) over Europe averaged over July and August for Pol 2.

Russell (2006) is met as the $\mathrm{mfb}$ is within $\pm 30 \%$ and the mfe is less than $50 \%$. As for $\mathrm{PM}_{10}$, the correlation is lower than the average of all models, but the rmse and the mfe are also lower.

\subsection{Spatial distribution}

\subsubsection{Over Europe}

Over Europe, Fig. 1 shows the $\mathrm{O}_{3}$ concentrations averaged over July and August for Pol 2. The spatial distribution of $\mathrm{O}_{3}$ shows similar patterns to previously computed distributions (e.g. Curci et al., 2009). $\mathrm{O}_{3}$ is high in southern Europe, especially over the Black Sea, the Mediterranean Sea and the Baltic Sea. $\mathrm{O}_{3}$ is low in northern Europe (Finland and northern Sweden). Over land, the highest concentrations are observed over Greece, Italy, Portugal, southern Spain and central Europe. $\mathrm{O}_{3}$ concentrations lower than the surrounding values are observed over large cities, such as Paris and Milan, because of NO titration. The NO titration is also observed along the sea traffic lines. Maps of $\mathrm{O}_{3}$ concentrations for simulations other than Pol 2 are not shown, as they are similar despite local differences. Taking into account biomass burning emissions (Pol 1 rather than Pol 2) only slightly increases $\mathrm{O}_{3}$ locally where biomass burning occurs, such as over Portugal. Using the EMEP rather than the TNO anthropogenic emission inventory, i.e. Pol 3 rather than Pol 2, leads to lower NO titration along the sea traffic lines and therefore higher $\mathrm{O}_{3}$. Using the MEGAN biogenic emission

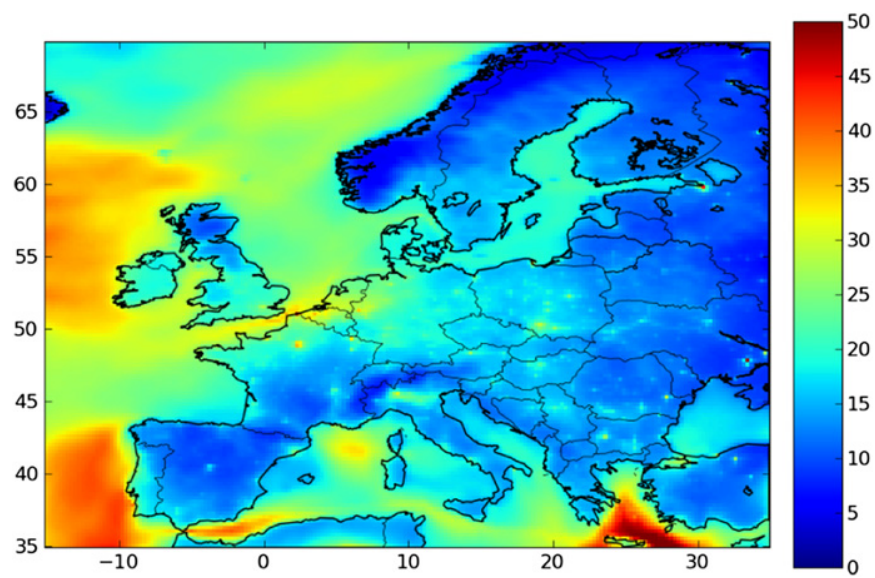

Fig. 2. Surface $\mathrm{PM}_{10}$ concentrations (in $\mu \mathrm{g} \mathrm{m}^{-3}$ ) over Europe averaged over July and August for Pol 2.
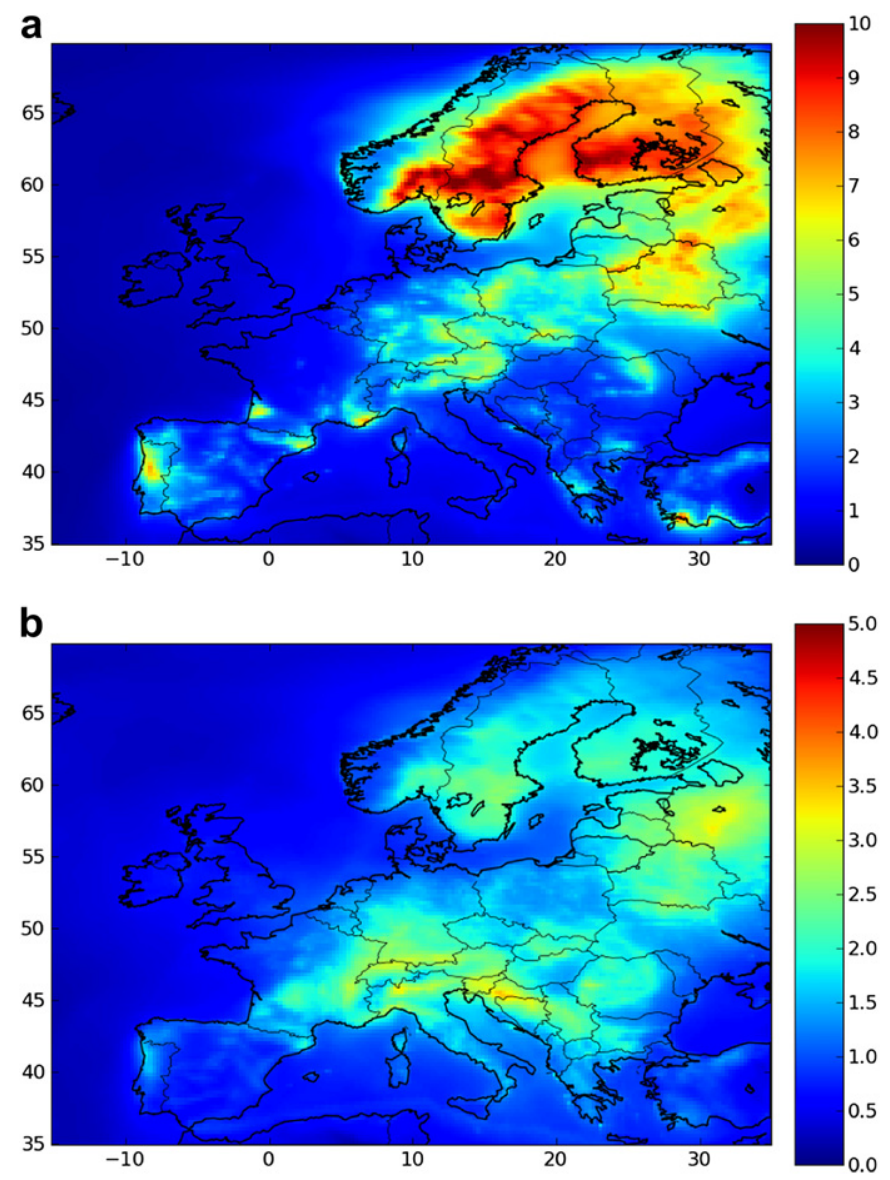

Fig. 3. Surface SOA concentrations (in $\mu \mathrm{g} \mathrm{m}^{-3}$ ) over Europe averaged over July and August using Simpson (Pol 3, upper panel) and MEGAN (Pol 4, lower panel) biogenic emission schemes.

scheme rather than Simpson, i.e. Pol 4 rather than Pol 3, leads to higher $\mathrm{O}_{3}$ over the northeastern part of the domain such as over Finland, where MEGAN biogenic emissions are much lower than Simpson's. This $\mathrm{O}_{3}$ increase with lower biogenic emissions is explained by the very high $\mathrm{VOC} / \mathrm{NO}_{\mathrm{x}}$ ratio over this part of the domain (see Fig. 7 and Section 4.1).

Fig. 2 shows $\mathrm{PM}_{10}$ concentrations averaged over July and August for Pol 2. The spatial distribution of $\mathrm{PM}_{10}$ shows similar patterns to previously computed distributions (e.g. Sartelet et al., 2007) with

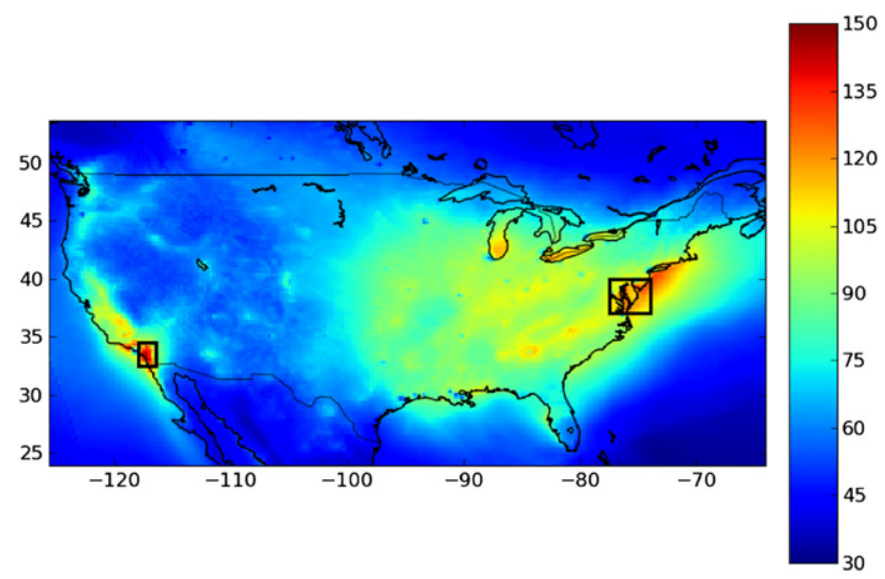

Fig. 4. Surface $\mathrm{O}_{3}$ concentrations (in $\mu \mathrm{g} \mathrm{m}^{-3}$ ) over North America averaged over July and August. 


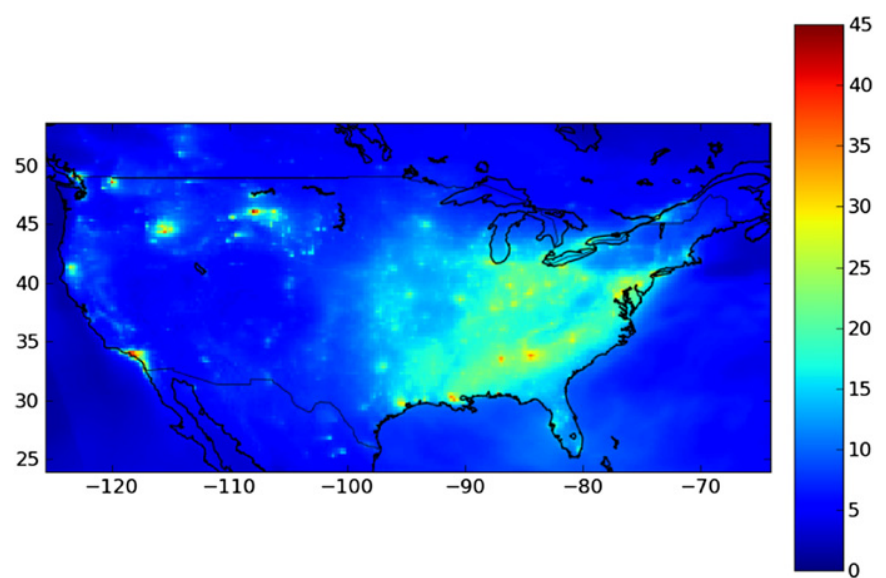

Fig. 5. Surface $\mathrm{PM}_{2.5}$ concentrations (in $\mu \mathrm{g} \mathrm{m}^{-3}$ ) over North America averaged over July and August.

high concentrations over cities, and areas such as northern Italy, northeastern Spain, and the Netherlands. Although the map of $\mathrm{PM}_{10}$ shows high concentrations around cities, the highest concentrations appear to be generated by maritime traffic and by sea-salt emissions. Maps of $\mathrm{PM}_{10}$ concentrations for simulations other than Pol 2 are not shown, as they are similar despite local differences. As for $\mathrm{O}_{3}$, the impact of maritime traffic on the formation of $\mathrm{PM}_{10}$ is slightly higher using the TNO rather than the EMEP anthropogenic emission inventory, i.e. Pol 3 rather than Pol 2. Furthermore, the variations of $\mathrm{PM}_{10}$ around cities are more sharply defined using TNO than EMEP. Using the MEGAN biogenic emission scheme rather than Simpson, i.e. Pol 4 rather than Pol 3, leads to lower $\mathrm{PM}_{10}$ over the northeastern part of the domain such as over Finland (see below).

Fig. 3 shows secondary organic aerosol (SOA) concentrations averaged over July and August using the Simpson (Pol 3, upper panel) and MEGAN (Pol 4, lower panel) biogenic emission schemes. The spatial distribution is very similar between Pol 2 and Pol 3, i.e. when changing the anthropogenic emission inventory. The overall spatial distribution agrees with previously published distributions (Kim et al., 2011a), and similarities in spatial distributions are found between Pol 3 and Pol 4: high SOA concentrations are observed in Portugal, southwestern France, northeastern Spain, southeastern France, northern Italy, Greece, western Russia, Finland and southern Sweden. However, the spatial distribution locally differs

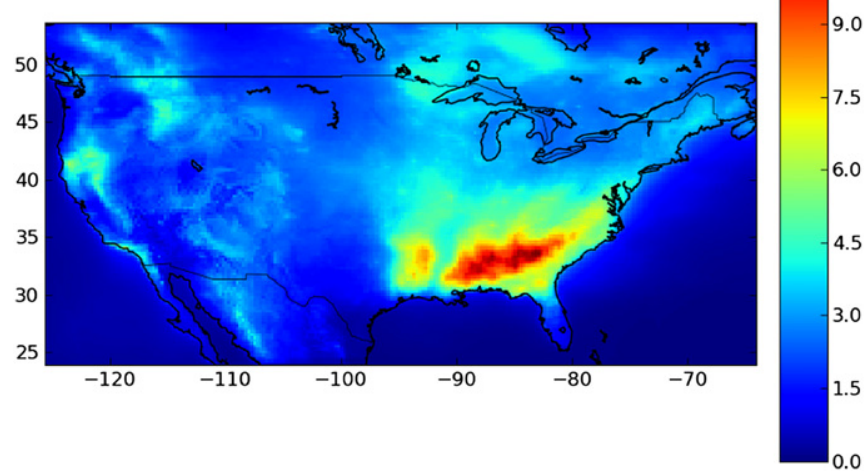

Fig. 6. Surface SOA concentrations (in $\mu \mathrm{g} \mathrm{m}^{-3}$ ) over North America averaged over July and August.
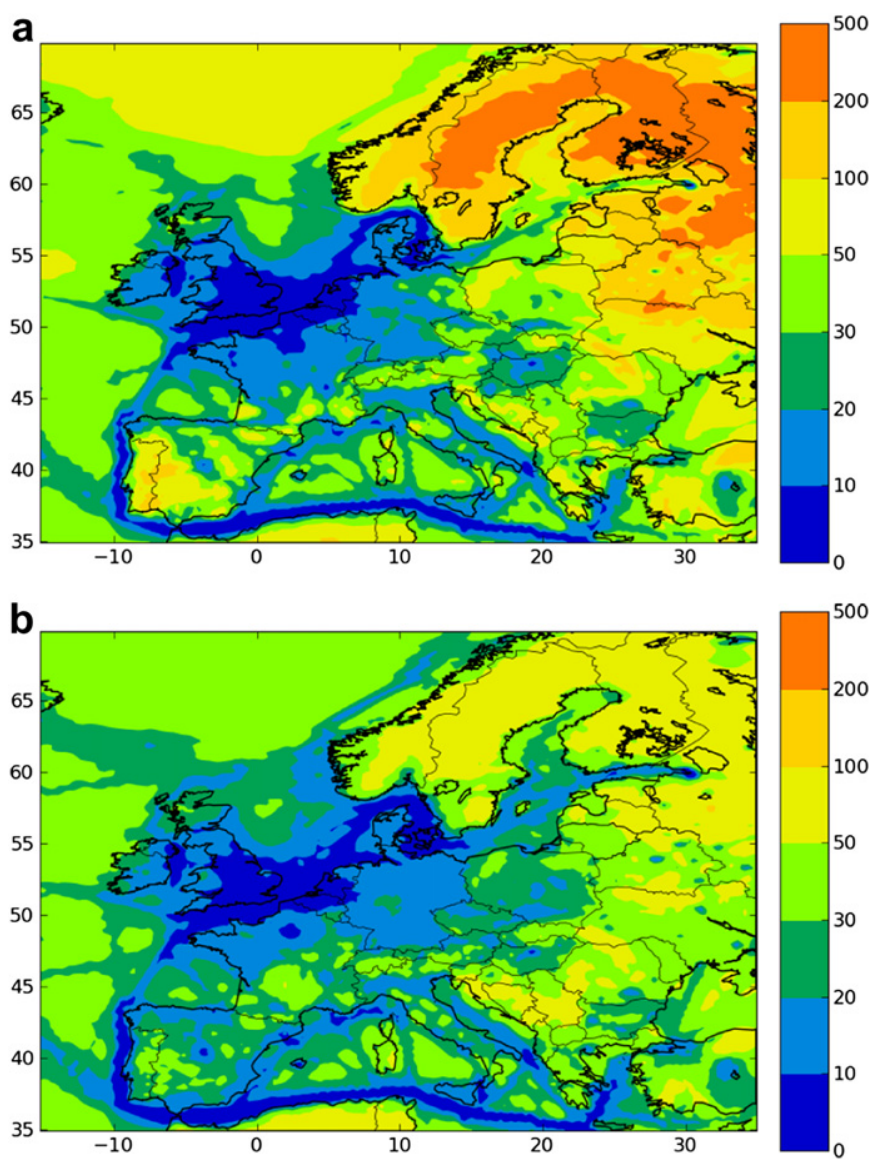

Fig. 7. Ratio of surface VOC over $\mathrm{NO}_{\mathrm{x}}$ concentrations averaged over July and August computed using Pol 3 (Simpson biogenic emission scheme, upper panel) and Pol 4 (MEGAN biogenic emission scheme, lower panel).

in areas such as in Poland, Croatia and central France. The amplitude of SOA concentrations is very different in Sweden and Finland when using Simpson and MEGAN: the concentrations are locally reduced by a factor of 5 when using MEGAN, because of lower biogenic emissions in MEGAN. On average over Europe, the SOA concentrations are reduced by a factor of 2 with MEGAN.

\subsubsection{Over North America}

$\mathrm{O}_{3}$ concentrations (see Fig. 4) are higher in the eastern United States than in the western U.S., except in California where high $\mathrm{O}_{3}$ is simulated. High $\mathrm{O}_{3}$ concentrations are also simulated along the east coast in the region of New York, as well as near Alabama in the southern U.S., and near the Michigan and Erie Great Lakes. The spatial distribution corresponds well to those simulated by others such as Luecken et al. (2008).

The map of $\mathrm{PM}_{2.5}$ concentrations averaged over July and August (Fig. 5) shows high concentrations especially around cities. The spatial distribution corresponds well to the ones simulated in Bailey et al. (2007), with high concentrations in California as well as in the eastern U.S. along the coast.

For SOA, the spatial distribution (see Fig. 6) corresponds to that obtained by Carlton et al. (2010): high concentrations are observed in the southeastern U.S., in California near Los Angeles as well as in the western U.S. However, the concentrations are much higher here with a maximum SOA concentration of $11 \mu \mathrm{g} \mathrm{m}^{-3}$, against about $1 \mu \mathrm{g} \mathrm{m}^{-3}$ in Carlton et al. (2010) for controllable biogenic SOA. However, the simulated SOA compare relatively well to observations, as shown in the Supplementary electronic materials: the 
average simulated concentration is equal to $3.6 \mu \mathrm{g} \mathrm{m}^{-3}$ against $2.8 \mu \mathrm{g} \mathrm{m}^{-3}$ estimated from measurements, with a mfb of $35.5 \%$. In the southeast where high concentrations are simulated, measurements from the database "AIRS" at the station AIRSUSGA1MCN $(-83.65,32.78)$ report an average concentration of $7.7 \mu \mathrm{g} \mathrm{m}^{-3}$ over July and August, whereas the simulated concentration is $9.3 \mu \mathrm{g} \mathrm{m} \mathrm{m}^{-3}$.

\section{Impact of biogenic emissions}

To estimate the contribution of biogenic emissions to $\mathrm{O}_{3}$ and $\mathrm{PM}$ under current conditions, the methodology of Pun et al. (2002) and Curci et al. (2009) is used. The simulation with all emissions is considered as the base case, and a simulation is performed without biogenic emissions (BVOC and NO) to calculate their contribution. As biogenic emissions interact with anthropogenic emissions to form $\mathrm{O}_{3}$ and secondary PM, a simulation is also performed without anthropogenic emissions to compare the impact.

\subsection{Over Europe}

Over Europe, the sensitivity simulations are performed for the three simulations Pol 2, Pol 3 and Pol 4.

Table 9 shows the mean concentrations of $\mathrm{O}_{3}, \mathrm{PM}_{10}$ (without $\mathrm{Na}$ and $\mathrm{Cl}$ ), SOA, isoprene SOA and terpene SOA averaged over Europe for July and August.

The impact of biogenic emissions on $\mathrm{O}_{3}$ concentrations is lower than the impact of anthropogenic emissions. Removing biogenic emissions reduces $\mathrm{O}_{3}$ concentrations by $10-11 \%$, whereas removing anthropogenic emissions reduces $\mathrm{O}_{3}$ concentration by $38-42 \%$. The impact of removing biogenic emissions is lower when MEGAN biogenic emission scheme is used instead of Simpson (10\% instead of $11 \%$ ). This slightly lower impact is a consequence of the lower VOC emissions in MEGAN than in Simpson. Removing anthropogenic emissions also has a lower impact with Pol $4(-38 \%)$ than with Pol 2 or Pol 3 ( -41 to $-42 \%$ ), that is when MEGAN biogenic emission scheme is used rather than Simpson. Differences in the impacts of emission computed using the two different anthropogenic emission inventories are small, as EMEP and TNO emissions are commensurate.

To understand the local variations of $\mathrm{O}_{3}$ concentrations when BVOC emissions are removed, the relative difference in $\mathrm{O}_{3}$ computed with all emissions and without BVOC emission is shown

\section{Table 9}

Contribution of biogenic emissions to concentration of surface $\mathrm{O}_{3}, \mathrm{PM}_{10}, \mathrm{SOA}$, isoprene SOA and terpene SOA averaged over Europe and over July and August (concentrations are in $\mu \mathrm{g} \mathrm{m}^{-3}$ ). Sea-salt (sodium and chloride) are not included in $\mathrm{PM}_{10}$.

\begin{tabular}{llcll}
\hline & & $\begin{array}{l}\text { Base } \\
\text { case }\end{array}$ & $\begin{array}{l}\text { No biogenic } \\
\text { emissions }\end{array}$ & $\begin{array}{l}\text { No anthropogenic } \\
\text { emissions }\end{array}$ \\
\hline $\mathrm{O}_{3}$ & Pol 2 & 61.9 & $55.2(-11 \%)$ & $36.6(-41 \%)$ \\
& Pol 3 & 63.0 & $56.0(-11 \%)$ & $36.6(-42 \%)$ \\
$\mathrm{PM}_{10}$ & Pol 4 & 61.9 & $56.0(-10 \%)$ & $38.2(-38 \%)$ \\
& Pol 2 & 9.4 & $7.4(-21 \%)$ & $4.4(-54 \%)$ \\
$\mathrm{SOA}$ & Pol 3 & 9.7 & $7.6(-21 \%)$ & $4.4(-55 \%)$ \\
& Pol 4 & 8.3 & $7.6(-8 \%)$ & $3.2(-62 \%)$ \\
& Pol 2 & 2.6 & $0.3(-87 \%)$ & $2.1(-16 \%)$ \\
Isoprene SOA & Pol 3 & 2.6 & $0.3(-88 \%)$ & $2.1(-16 \%)$ \\
& Pol 4 & 1.1 & $0.3(-72 \%)$ & $1.0(-15 \%)$ \\
\multirow{2}{*}{ Terpene SOA } & Pol 2 & 0.6 & $0.0(-94 \%)$ & $0.4(-24 \%)$ \\
& Pol 3 & 0.6 & $0.0(-94 \%)$ & $0.4(-24 \%)$ \\
& Pol 4 & 0.2 & $0.0(-84 \%)$ & $0.2(-22 \%)$ \\
& Pol 2 & 1.7 & $0.1(-93 \%)$ & $1.5(-10 \%)$ \\
& Pol 3 & 1.7 & $0.1(-93 \%)$ & $1.5(-10 \%)$ \\
\hline
\end{tabular}

in Fig. 8 for Pol 2, Pol 3 and Pol 4. Fig. 7 shows the $\mathrm{VOC} / \mathrm{NO}_{\mathrm{x}}$ concentration ratio for Pol 3 and Pol 4. The regions where the impact of biogenic emissions is high in Fig. 8 are strongly correlated to those where the $\mathrm{VOC} / \mathrm{NO}_{\mathrm{x}}$ ratio is low compared to surroundings in Fig. 7 (e.g. Milan, northeastern Spain, central Europe). The decrease in $\mathrm{O}_{3}$ concentration is as high as $30 \%$ near cities, which are surrounded by biogenic emissions, such as Milan in Italy, Porto in Portugal or Warsaw in Poland. Around these cities, although BVOC emissions are high, the $\mathrm{O}_{3}$ regime is probably VOC limited, leading to a strong decrease in $\mathrm{O}_{3}$ concentrations when BVOC are removed. On the opposite, $\mathrm{O}_{3}$ increases by as much as $10-20 \%$ in northern
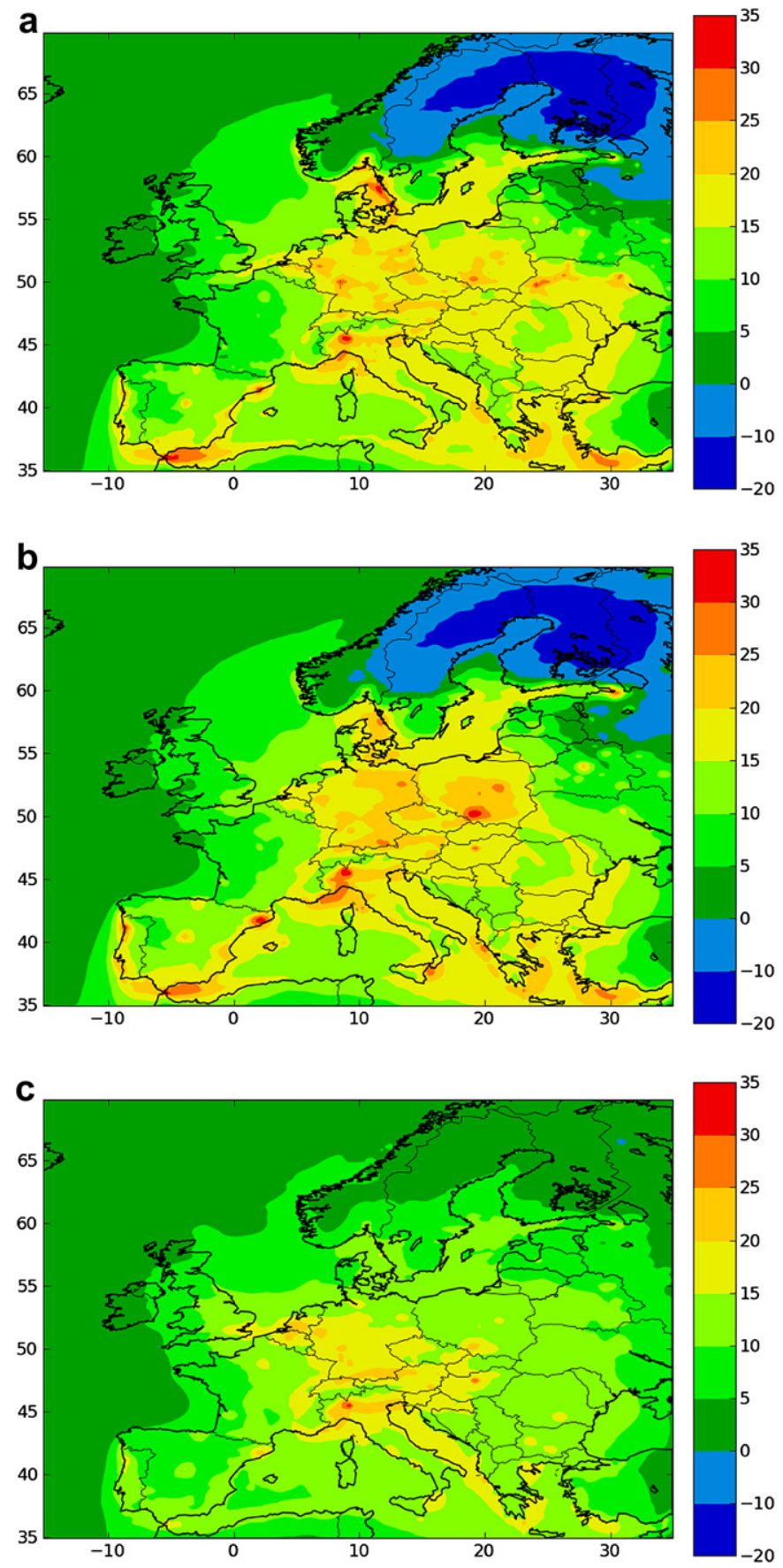

Fig. 8. Relative difference between surface $\mathrm{O}_{3}$ concentrations (in \%) averaged over July and August computed with and without biogenic emissions, using Pol 2 (upper panel), Pol 3 (middle panel) and Pol 4 (lower panel). 
Sweden, Finland and part of Russia, where the $\mathrm{VOC} / \mathrm{NO}_{\mathrm{x}}$ ratio becomes higher than 200. This increase is removed when using MEGAN. Because BVOC emissions over Sweden and Finland are lower in MEGAN, the $\mathrm{VOC} / \mathrm{NO}_{\mathrm{x}}$ ratio is lower and $\mathrm{O}_{3}$ concentrations are not modified by removing BVOC emissions. Although the impact of BVOC emissions on $\mathrm{O}_{3}$ is almost the same for the two different anthropogenic emission inventories, local differences are important in central Europe near cities such as in Ukraine and Lithuania. Sea-traffic also has a larger impact using Pol 2 (TNO) than Pol 3 (EMEP).
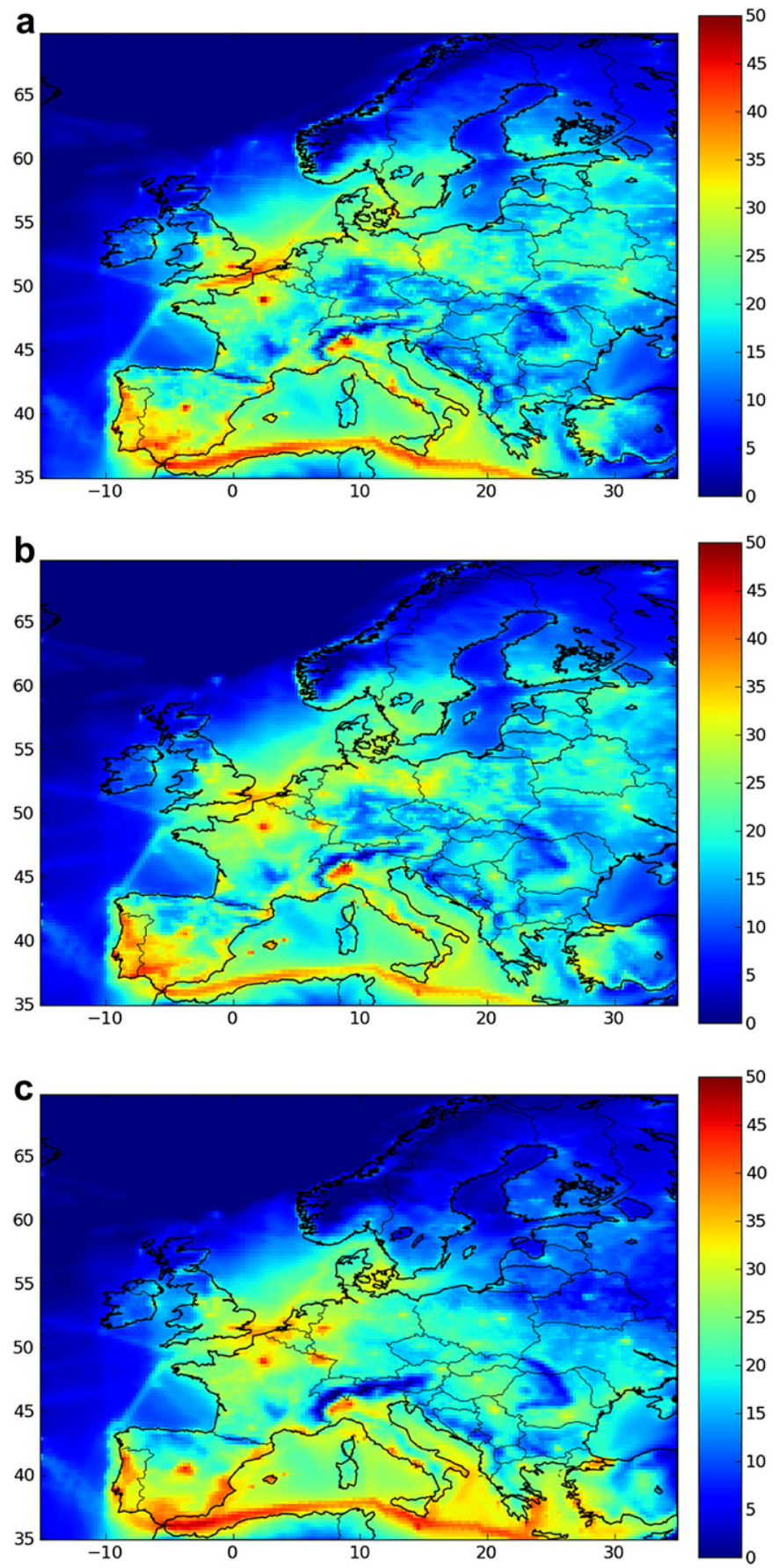

Fig. 9. Relative difference between surface SOA concentrations (in \%) averaged over July and August computed with and without anthropogenic emissions, using Pol 2 (upper panel), Pol 3 (middle panel) and Pol 4 (lower panel).
$\mathrm{PM}_{10}$ is much more impacted by anthropogenic than biogenic emissions: the concentration decreases by $8-21 \%$ on average when biogenic emissions are removed, whereas it decreases by as much as $54-62 \%$ when anthropogenic emissions are removed. As for $\mathrm{O}_{3}$, differences in the impacts of emission computed using the two different anthropogenic emission inventories are small. The impact of removing biogenic emissions is lower when using MEGAN rather than the Simpson biogenic emission scheme (8\% for MEGAN and $21 \%$ for Simpson).

As SOA is mostly formed from isoprene (20-23\%) and terpenes (62-67\%) in our simulations, it is strongly impacted by biogenic emissions. SOA is very low when biogenic emissions are ignored: the concentrations are reduced by $87-88 \%$ on average in Pol 2 and Pol 3 and by $72 \%$ in Pol 4 where MEGAN is used. However, removing anthropogenic emissions only reduces SOA by $15-16 \%$.

Locally, removing anthropogenic emissions may lead to a large decrease in SOA as shown in Fig. 9. SOA is reduced by as much as 40-50\% along the maritime traffic lines, as well as around large cities such as Milan or Paris. The map of the relative difference of SOA when all emissions are taken into account and when biogenic emissions are removed is strongly correlated to the map of $\mathrm{NO}_{\mathrm{x}}$ emissions, with emphasis where biogenic emissions are high (such as Portugal, southern Spain and Poland). In Fig. 9, the impact of anthropogenic emissions on SOA is shown only for Pol 3 and Pol 4, as the impact is very similar for Pol 2 and Pol 3, as suggested by the average numbers of Table 9. Differences between Pol 3 and Pol 4 arise mostly in Germany, Poland, Estonia and Belarus,
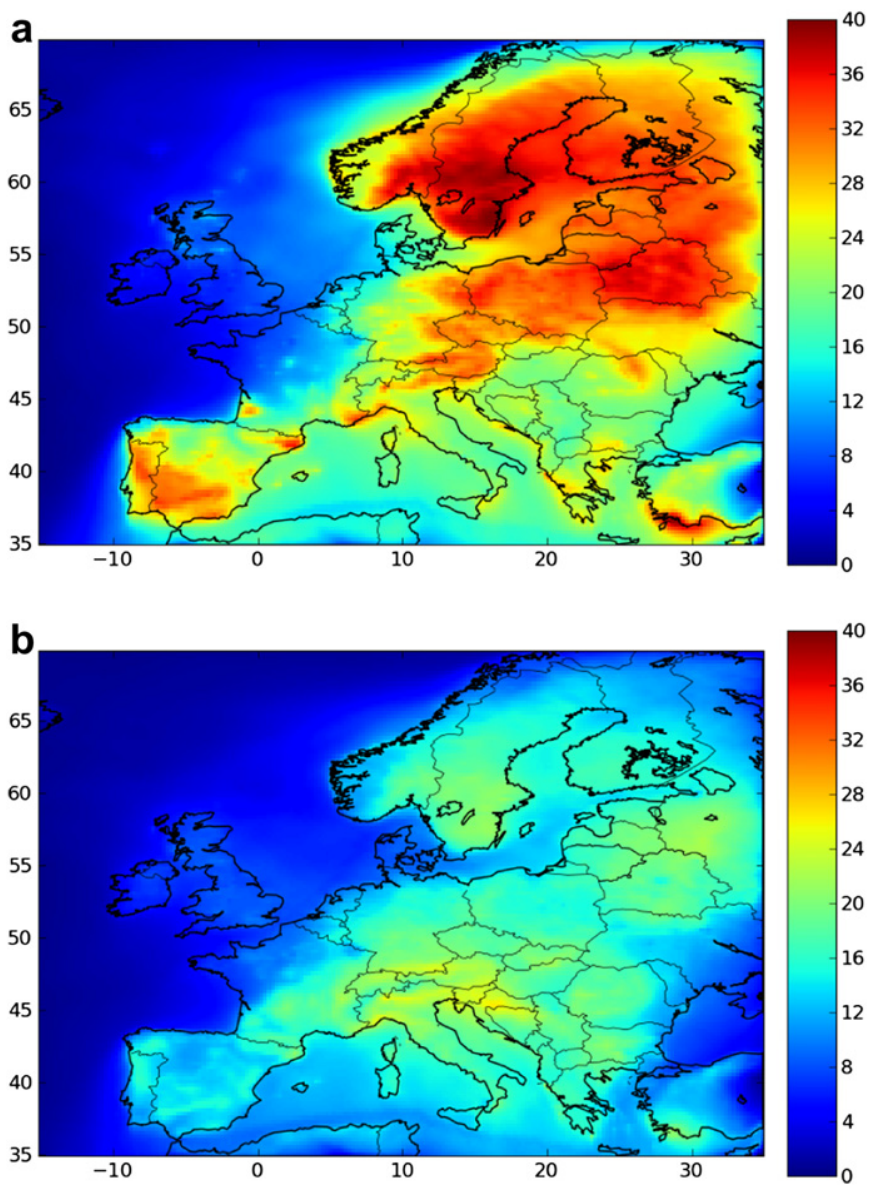

Fig. 10. Relative difference averaged over July and August between surface anthropogenic SOA concentrations (in \%) computed with and without biogenic emissions, using Pol 3 (upper panel) and Pol 4 (lower panel). 
Table 10

Contribution of biogenic emissions to concentration of surface $\mathrm{O}_{3}, \mathrm{PM}_{10}, \mathrm{SOA}$ isoprene SOA and terpene SOA averaged over North America and over July and August (concentrations are in $\mu \mathrm{g} \mathrm{m}^{-3}$ ). Sea-salt (sodium and chloride) are not included in $\mathrm{PM}_{10}$.

\begin{tabular}{lccc}
\hline & Base case & No biogenic emissions & No anthropogenic emissions \\
\hline $\mathrm{O}_{3}$ & 64.5 & $51.5(-20 \%)$ & $33.2(-49 \%)$ \\
$\mathrm{PM}_{10}$ & 9.3 & $8.1(-14 \%)$ & $4.6(-50 \%)$ \\
$\mathrm{SOA}$ & 2.3 & $0.2(-90 \%)$ & $2.1(-10 \%)$ \\
Isoprene SOA & 0.5 & $0.0(-93 \%)$ & $0.4(-16 \%)$ \\
Terpene SOA & 1.6 & $0.1(-94 \%)$ & $1.5(-7 \%)$ \\
\hline
\end{tabular}

southwestern Spain and southwestern France, which are places where the two biogenic emission schemes lead to different patterns of SOA concentrations, and where significant anthropogenic emissions are present. In contrast, despite large differences in SOA concentrations simulated in Pol 3 and Pol 4 over northern Sweden and northern Finland, the impact of anthropogenic emissions is low over these countries because anthropogenic emissions are low.

Removing biogenic emissions does not only affect the biogenic compounds of SOA, but also the anthropogenic ones. By providing an absorbing organic mass, the biogenic compounds of particles facilitate the condensation of anthropogenic compounds. The absolute impact is low as the concentration of anthropogenic SOA is low compared to biogenic SOA at the continental scale. However, the relative impact of biogenic SOA on anthropogenic SOA may be as high as $40 \%$, as shown in Fig. 10, which shows the relative difference of anthropogenic SOA when all emissions are taken into account and when biogenic emissions are ignored for Pol 3 and Pol 4. The map describing the impact of biogenic SOA on anthropogenic SOA is strongly correlated with the map of biogenic SOA concentrations. The relative impact is higher in Pol 3 than in Pol 4 as biogenic emissions are higher.

\subsection{Over North America}

The contributions of biogenic and anthropogenic emissions to domain-wide averaged concentrations of $\mathrm{O}_{3}, \mathrm{PM}_{10}$, SOA, isoprene SOA and terpene SOA over North America are shown in Table 10.

Removing biogenic emissions reduces $\mathrm{O}_{3}$ concentrations by about $20 \%$ on average, whereas removing anthropogenic emissions reduces $\mathrm{O}_{3}$ concentrations by $49 \%$. This result is consistent with the seminal work of Pun et al. (2002) who estimated the contribution of biogenic emissions to $\mathrm{O}_{3}$ to be less than $23 \%$ in Nashville/TN and

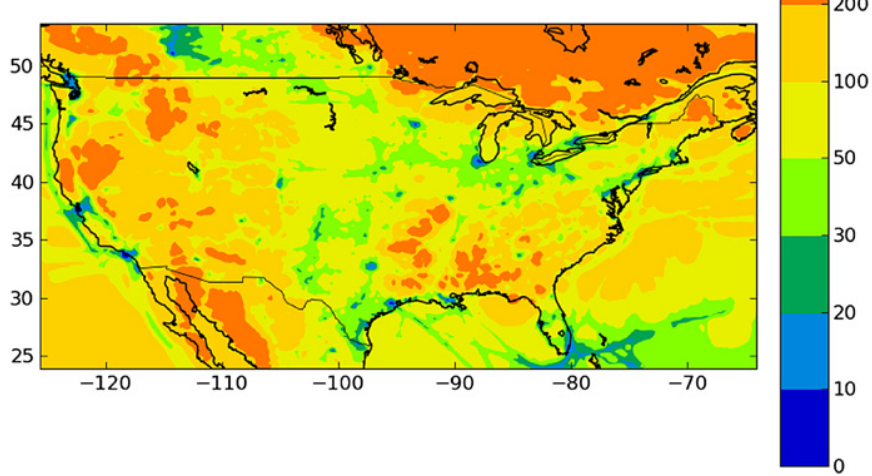

Fig. 11. Ratio of surface $\mathrm{VOC}$ over $\mathrm{NO}_{\mathrm{x}}$ concentrations averaged over July and August.

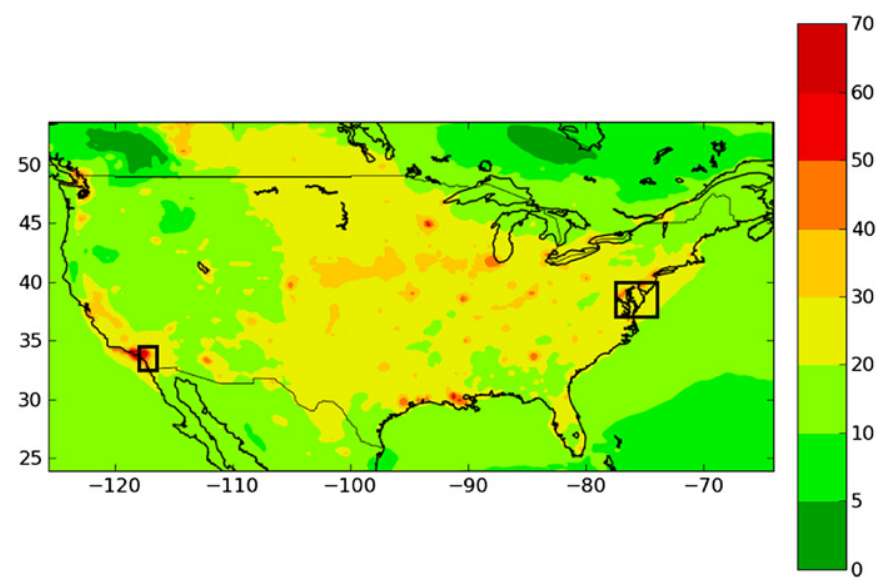

Fig. 12. Relative difference between surface $\mathrm{O}_{3}$ concentrations (in \%) averaged over July and August computed with and without biogenic emissions.

the northeastern U.S., with a contribution between $22 \%$ and $34 \%$ in urban areas. The contribution of biogenic emissions to $\mathrm{O}_{3}$ is also observed to be regionally more important around urban areas, especially in the northeastern U.S. and in California near Los Angeles, as shown in Fig. 12, which depicts the relative difference of hourly $\mathrm{O}_{3}$ concentrations averaged over July and August when all emissions are taken into account and when biogenic emissions are removed. $\mathrm{O}_{3}$ is found to be $26 \%$ and $38 \%$ lower in the northeastern U.S. (near Washington DC and New Jersey) and California near Los Angeles, respectively (see rectangles in Fig. 12). A high decrease in $\mathrm{O}_{3}$ concentration is observed over large cities close to high-VOC emission areas when biogenic emissions are removed. As for Europe, the regions where the impact of biogenic emissions is high correspond to those where the $\mathrm{VOC} / \mathrm{NO}_{\mathrm{x}}$ concentration ratio is low compared to surroundings (large urban centers), as seen by comparing Figs. 11 and 12.

$\mathrm{PM}_{10}$ is not much impacted by biogenic emissions: the concentration decreases by $14 \%$ on average when biogenic emissions are removed, whereas it decreases by as much as $50 \%$ when anthropogenic emissions are removed. However, biogenic emissions largely contribute to secondary organic aerosols (SOA). If they are not considered, SOA decrease by $90 \%$ on average over the domain. In comparison, removing anthropogenic emissions only reduces SOA by $10 \%$ on average. SOA are composed mostly of isoprene $(23 \%)$ and terpene $(67 \%)$ oxidation products. Isoprene and

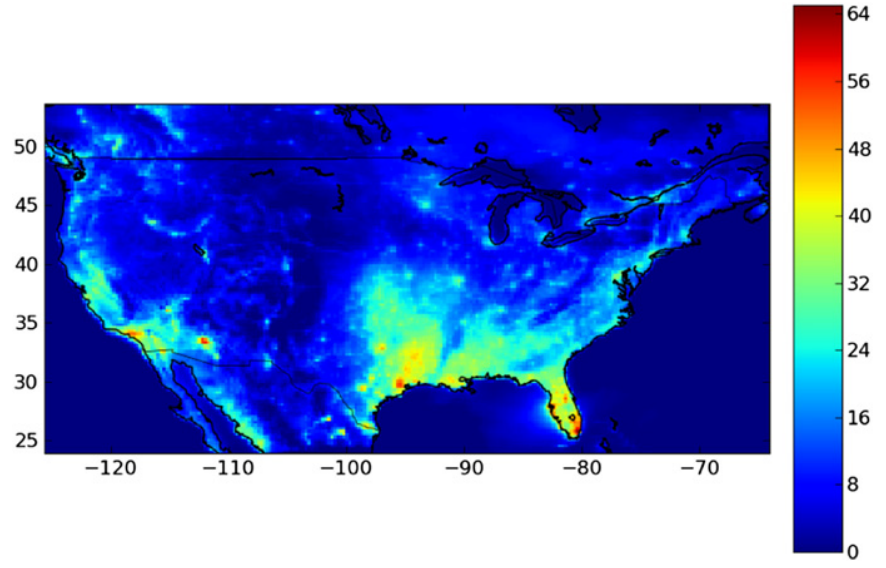

Fig. 13. Relative difference between surface SOA concentrations (in \%) averaged over July and August computed with and without anthropogenic emissions. 


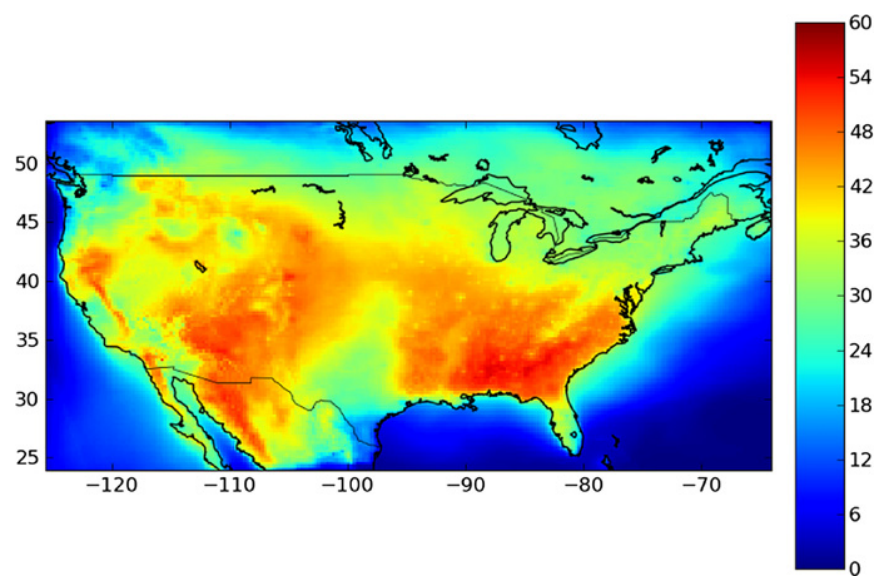

Fig. 14. Relative difference between surface anthropogenic SOA concentrations (in \%) averaged over July and August computed with and without biogenic emissions.

terpene SOA are reduced by $16 \%$ and $7 \%$, respectively, on average over the domain when anthropogenic emissions are removed. However, locally, the reduction may be larger. Large cities, such as Los Angeles, Atlanta, Birmingham, Saint Louis, Washington DC, Chicago and Minneapolis may clearly be identified by looking at the map of the relative difference of SOA concentrations when all emissions are considered and when anthropogenic emissions are removed (Fig. 13). Removing anthropogenic emissions leads to a large decrease of biogenic SOA near these large cities. A decrease as large as $60 \%$ is observed locally around cities such as Los Angeles and Houston. A decrease on the order of $60 \%$ around cities is consistent with the results of Carlton et al. (2010).

As for the European study, removing biogenic emissions does not only affect the biogenic compounds of SOA, but also the anthropogenic ones. The relative impact of biogenic SOA on anthropogenic SOA may be as high as $60 \%$, as shown in Fig. 14, which shows the relative difference of anthropogenic SOA when all emissions are taken into account and when biogenic emissions are ignored.

\section{Conclusion}

Over both Europe and NA, Polyphemus performances are satisfactory for $\mathrm{O}_{3}$ and $\mathrm{PM}$ with respect to criteria used in the literature, as well as in comparison to other AQMEII models. Over Europe, the simulation with biomass burning emissions overestimate $\mathrm{PM}_{2.5}$ over Portugal, probably because the fire emission height is not accurately modeled.

The impact of biogenic emissions is higher on average over NA than over Europe for $\mathrm{O}_{3}$, and it is commensurate for SOA. Locally, the impacts of biogenic emissions tends to be higher in NA than in Europe because of the presence in NA of large urban centers surrounded by regions of high biogenic emissions.

Both over Europe and NA, the impact of biogenic emissions on $\mathrm{O}_{3}(-10$ to $-20 \%)$ is lower than the impact of anthropogenic emissions ( -38 to $-49 \%)$. The regions where the impact of biogenic emissions is high correspond to those where the $\mathrm{VOC} / \mathrm{NO}_{\mathrm{x}}$ ratio is low compared to surroundings. For SOA, which are mostly biogenics, the impact of biogenic emissions (72-90\%) is much greater than the impact of anthropogenic emissions (10-16\%). However, locally, the impact of anthropogenic emissions may be high (up to 50\%, both in NA and Europe), stressing the fact that even biogenic SOA may be controlled for a large part by controlling anthropogenic emissions. The biogenic SOA reduction when all anthropogenic emissions are eliminated varies depending on the chemical precursors: isoprene SOA is more reduced than terpene SOA because of differences in their volatility. Anthropogenic SOA are also impacted by biogenic emissions (absorbing organic mass for SOA), with a relative impact that can be as high as $40 \%$ locally. To accurately model SOA, it is, therefore, necessary to accurately model both biogenic and anthropogenic SOA.

Over Europe, for $\mathrm{O}_{3}$ and SOA, the impact of biogenic emissions is lower in Pol 4 (which uses the MEGAN biogenic emission scheme) than in Pol 2 or Pol 3 (which use the Simpson biogenic emission scheme). The largest differences between the impacts simulated with Pol 4 compared to those simulated with Pol 2 and Pol 3 show that uncertainties in the biogenic emission schemes used here are larger than uncertainties in the two anthropogenic emission inventories.

\section{Acknowledgements}

This work was supported by the French national program INSULEFE-CHAT/ADEME (project AO2011-665626).

\section{Appendix. Supplementary material}

Supplementary material associated with this article can be found, in the online version, at doi:10.1016/j.atmosenv.2011.10.046.

\section{References}

Bailey, E., Gautney, L., Kelsoe, J., Jacobs, M., Mao, Q., Condrey, J., Pun, B., Wu, S.-Y., Seigneur, C., Douglas, S., Haney, J., Kumar, N., 2007. A comparison of the performance of four air quality models for the Southern Oxidants Study episode in July 1999. J. Geophys. Res. 112, D05306.

Bianconi, R., Galmarini, S., Bellasio, R., 2004. Web-based system for decision support in case of emergency: ensemble modelling of long-range atmospheric dispersion of radionuclides. Environ. Model. Software 19, 401-411.

Boylan, J., Russell, A., 2006. PM and light extinction model performance metrics, goals, and criteria for three-dimensional air quality models. Atmos. Environ. 40, 4946-4959.

Carlton, A., Pinder, R., Bhave, P., Pouliot, G., 2010. To what extent can biogenic SOA be controlled? Environ. Sci. Technol. 44, 3376-3380.

Curci, G., Beekmann, M., Vautard, R., Smiatek, G., Steinbrecher, R., Theloke, J., Friedrich, R., 2009. Modelling study of the impact of isoprene and terpene biogenic emissions on European ozone levels. Atmos. Environ. 43, 1444-1455.

Debry, É., Fahey, K., Sartelet, K., Sportisse, B., Tombette, M., 2007. Technical Note: A new SIze REsolved Aerosol Model (SIREAM). Atmos. Chem. Phys. 7 (6) 1537-1547.

Guenther, A., Hewitt, N., Erickson, D., Fall, R., Geron, C., Graedel, T., Harley, P., Klinger, L., Lerdau, M., McKay, W., Pierce, T., Scholes, B., Steinbrecher, R. Tallamraju, R., Taylor, J., Zimmerman, P., 1995. Global model of natural volatile organic compounds emissions. J. Geophys. Res. 100, 8873-8892.

Guenther, A., Karl, T., Harley, P., Wiedinmyer, C., Palmer, P., Geron, C., 2006. Estimates of global terrestrial isoprene emissions using MEGAN (Model of Emissions of Gases and Aerosols from Nature). Atmos. Chem. Phys. 6, 3181-3210.

Helmig, D., Klinger, A., Vierling, L., Zimmerman, P., Geron, C., 1999a. Biogenic volatile organic compound emissions (bvocs) i. identifications from three continental sites in the U.S. Chemosphere 38, 2163-2187.

Helmig, D., Klinger, A., Vierling, L., Zimmerman, P., Geron, C., 1999b. Biogenic volatile organic compound emissions (bvocs) ii. landscape fluxes potentials from three continental sites in the U.S. Chemosphere 38, 2189-2204.

Hodzic, A., Madronich, S., Bohn, B., Massie, S., Menut, L, Wiedinmyer, C., 2007. Wildfire particulate matter in Europe during summer 2003: meso-scale modeling of smoke emissions, transport and radiative effects. Atmos. Chem. Phys. 7, 4043-4064.

Hogrefe, C., Isukapalli, S., Tang, X., Georgopoulos, P., He, S., Zalewsky, E., Hao, W. Ku, J., Key, T., Sistla, G., 2011. Impact of biogenic emission uncertainties on the simulated response of ozone and fine Particulate Matter to anthropogenic emission reductions. J. Air Waste Manag. Assoc. 61, 92-108.

Hoyle, C., Boy, M., Donahue, N., Fry, J., Glasius, M., Guenther, A., Hallar, A., Huff Hartz, K., Petters, M., Petj, T., Rosenoern, T., Sullivan, A., 2011. A review of the anthropogenic influence on biogenic secondary organic aerosol. Atmos. Chem. Phys. 11, 321-343.

Johnson, D., Utembe, S., Jenkin, M., Derwent, R., Hayman, G., Alfarra, M., Coe, H. McFiggans, G., 2006. Simulating regional scale secondary organic aeroso formation during the TORCH 2003 campaign in the southern UK. Atmos. Chem. Phys. 6, 403-418.

Kim, Y., Couvidat, F., Sartelet, K., Seigneur, C., 2011a. Comparison of different gasphase mechanisms and aerosol modules for simulating particulate matter 
formation. J. Air Waste Manage. Assoc. 61, 1218-1226. doi:10.1080/10473289. 2011.603999.

Kim, Y., Sartelet, K., Seigneur, C., 2009. Comparison of two gas-phase chemical kinetic mechanisms of ozone formation over Europe. J. Atmos. Chem. 62 (2), 89-119.

Kim, Y., Sartelet, K., Seigneur, C., 2011b. Formation of secondary aerosols: impact of the gas-phase chemical mechanism. Atmos. Chem. Phys. 11, 583-598.

Koo, B., Chien, C., Tonnesen, G., Morris, R., Johnson, J., Sakulyanontvittaya, T. Piyachaturawat, P., Yarwood, G., 2011. Natural emissions for regional modeling of background ozone and particulate matter and impacts on emissions control strategies. Atmos. Environ. 44 (19), 2372-2382.

Luecken, D., Phillips, S., Sarwar, G., Jang, C., 2008. Effects of using the CB05 vs. SAPRC99 vs. CB4 chemical mechanism on model predictions: ozone and gasphase photochemical precursor concentrations. Atmos. Environ. 42, 5805-5820.

Monahan, E., Spiel, D., Davidson, K., 1986. A model of marine aerosol generation via whitecaps and wave disruption. In: Oceanic Whitecaps. D. Reidel, pp. 167-174

Mueller, S., Mallard, J., 2011. Contributions of natural emissions to ozone and $\operatorname{PM}(2.5)$ as simulated by the community multiscale air quality (CMAQ) model. Environ. Sci. Technol. 45 (11), 4817-4823.

Ostro, B., Chestnut, L., 1998. Assessing the health benefits of reducing particulate matter air pollution in the united states. Environ. Res. 76, 94-106.

Pouliot, G., Pierce, T., Denier van der Gon, H., Schaap, M., Moran, M., Nopmongcol, U. 2012. Comparing emissions inventories and model-ready emissions datasets between Europe and North America for the AQMEII project. Atmos. Environ. 53, $4-14$.

Pun, B., Wu, S.-Y., Seigneur, C., 2002. Contribution of biogenic emissions to the formation of ozone and particulate matter in the eastern United States. Environ. Sci. Technol. 36, 3586-3596.

Rao, S., Galmarini, S., Puckett, K., 2011. Air quality model evaluation international initiative (AQMEII): advancing the state of the science in regional photochemical modeling and its applications. Bull. Am. Meteorol. Soc. 92, 23-30.

Real, E., Sartelet, K., 2011. Modeling of photolysis rates over Europe: impact on chemical gaseous species and aerosols. Atmos. Chem. Phys. 11, 1711-1727.

Roustan, Y., Sartelet, K., Tombette, M., Debry, É., Sportisse, B., 2010. Simulation of aerosols and gas-phase species over Europe with the POLYPHEMUS system. Part II: model sensitivity analysis for 2001. Atmos. Environ. 44 (34), 4219-4229.
Russell, A., Dennis, R., 2000. NARSTO critical review of photochemical models and modeling. Atmos. Environ. 34, 2283-2324.

Sartelet, K., Debry, É., Fahey, K., Roustan, Y., Tombette, M., Sportisse, B., 2007. Simulation of aerosols and gas-phase species over Europe with the Polyphemus system: part I - model-to-data comparison for 2001. Atmos. Environ. 41 (29), 6116-6131.

Sartelet, K., Hayami, H., Sportisse, B., 2010. MICS Asia phase II sensitivity to the aerosol module. Atmos. Environ. 42 (15), 3562-3570.

Seinfeld, J., Pandis, S., 1998. Atmospheric Chemistry and Physics. Wiley-interscience. Simpson, D., Winiwarter, W., Brjesson, G., Cinderby, S., Ferreiro, A., Guenther, A., Hewitt, C., Janson, R., Khalil, M., Owen, S., Pierce, T., Puxbaum, H., Shearer, M., Skiba, U., Steinbrecher, R., Tarrason, L., Oquist, M., 1999. Inventorying emissions from nature in Europe. J. Geophys. Res. 104 (D7), 8113-8152.

Steinbrecher, R., Smiatek, G., Kble, R., Seufert, G., Theloke, J., Hauff, K., Ciccioli, P., Vautard, R., Curci, G., 2009. Intra- and inter-annual variability of VOC emissions from natural and semi-natural vegetation in Europe and neighbouring countries. Atmos. Environ. 43, 1380-1391.

Stockwell, W.R., Kirchner, F., Kuhn, M., Seefeld, S., 1997. A new mechanism for regional atmospheric chemistry modeling. J. Geophys. Res. 102 (D22), 25847-25879.

Struzewska, J., Kaminski, J.W., 2008. Formation and transport of photooxidants over Europe during the July 2006 heat wave - observations and GEM-AQ model simulations. Atmos. Chem. Phys. 8, 721-736.

Vautard, R., Moran, M., Solazzo, E., Gilliam, R., Volker, M., Bianconi, R., Chemel, C., Ferreira, J., Geyer, B., Hansen, A.B., Jericevic, A., Prank, M., Segers, A., Silver, J.D., Werhahn, J., Wolke, R., Rao, S.T., Galmarini, S., 2012. Evaluation of the meteorological forcing used for the Air Quality Model Evaluation International Initiative (AQMEII) air quality simulations. Atmos. Environ. 53, 38-50.

Yarwood, G., Rao, S., Yocke, M., Whitten, G., 2005. Updates to the Carbon Bond Chemical Mechanism: CB05 Final Report to the US EPA. RT-0400675 Available at: http://www.camx.com/publ/pdfs/CB05_Final_Report_120805.pdf.

Yu, H., Kaufman, Y., Chin, M., Feingold, G., Remer, L., Anderson, T., Balkanski, Y., Bellouin, N., Boucher, O., Christopher, S., DeCola, P., Kahn, R., Koch, D., Loeb, N., Reddy, M., Schulz, M., Takemura, T., Zhou, M., 2006. A review of measurementbased assessments of the aerosol direct radiative effect and forcing. Atmos. Chem. Phys. 6, 613-666 